\title{
Casticin induces DNA damage and inhibits DNA repair-associated protein expression in B16F10 mouse melanoma cancer cells
}

\author{
YUNG-LUEN SHIH ${ }^{1-3^{*}}$, JASON CHOU ${ }^{4 *}$, MING-YANG YEH $^{5}$, HSIAO-MIN CHOU ${ }^{1}$, HSIU-CHEN CHOU ${ }^{1}$, \\ HSU-FENG LU ${ }^{6,7}$, HUNG-SHENG SHANG $^{8}$, FU-SHIN CHUEH ${ }^{9}$, YUNG-LIN CHU ${ }^{10}$, \\ SHU-CHING HSUEH ${ }^{7,11}$ and JING-GUNG CHUNG ${ }^{12,13}$
}

\begin{abstract}
${ }^{1}$ Department of Pathology and Laboratory Medicine, Shin Kong Wu Ho-Su Memorial Hospital, Taipei, Taiwan;
${ }^{2}$ School of Medical Laboratory Science and Biotechnology, Taipei Medical University, Taipei, Taiwan; ${ }^{3}$ School of Medicine,

Fu-Jen Catholic University, New Taipei, Taiwan; ${ }^{4}$ Department of Pathology, Cheng-Hsin General Hospital, Taipei, Taiwan; ${ }^{5}$ Office of Director, Cheng-Hsin General Hospital, Taipei, Taiwan; ${ }^{6}$ Department of Restaurant, Hotel and Institutional Management, Fu-Jen Catholic University, New Taipei, Taiwan; ${ }^{7}$ Department of Clinical Pathology, Cheng-Hsin General Hospital, Taipei, Taiwan; ${ }^{8}$ Department of Pathology, National Defense Medical Center, Division of Clinical Pathology, Tri-Service General Hospital, Taipei, Taiwan; ${ }^{9}$ Department of Health and Nutrition Biotechnology, Asia University, Taichung, Taiwan; ${ }^{10}$ International Master's Degree Program in Food Science, International College, National Pingtung University of Science and Technology, Pingtung, Taiwan; ${ }^{11}$ Division of Hematology and Oncology, Cheng-Hsin General Hospital, Taipei, Taiwan; ${ }^{12}$ Department of Biological Science and Technology, China Medical University, Taichung, Taiwan; ${ }^{13}$ Department of Biotechnology, Asia University, Taichung, Taiwan, R.O.C.
\end{abstract}

Received February 1, 2016; Accepted March 9, 2016

DOI: 10.3892/or.2016.5027

\begin{abstract}
Casticin, a polymethoxyflavone, has been demonstrated to possess anticancer activities, yet no study has shown in detail that casticin induces DNA damage in lung cancer cells. The purpose of this study was to investigate the possible molecular mechanisms of casticin which induce DNA damage and nuclear condensation in murine melanoma cancer B16F10 cells. In this study, by examining and capturing images using phase contrast microscopy, we found that casticin induced cell morphological changes. Moreover, it decreased the total number of viable cells which was measured by flow cytometry. Casticin-induced DNA damage and nuclear DNA condensation were measured by DAPI staining, respectively. Western
\end{abstract}

Correspondence to: Professor Jing-Gung Chung, Department of Biological Science and Technology, China Medical University. 91 Hsueh-Shih Road, Taichung 404, Taiwan, R.O.C.

E-mail: jgchung@mail.cmu.edu.tw

Dr Shu-Ching Hsueh, Division of Hematology and Oncology, Cheng-Hsin General Hospital, 45 Cheng Hsin Street, Pai-Tou, Taipei 112, Taiwan, R.O.C.

E-mail: ch1835@chgh.org.tw

${ }^{*}$ Contributed equally

Key words: casticin, DNA condensation, DAPI staining, murine melanoma B16F10 cells blotting indicated that casticin decreased the protein levels of $O^{6}$-methylguanine-DNA methyltransferase (MGMT), breast cancer 1, early onset (BRCA1), mediator of DNA damage checkpoint 1 (MDC1), DNA-dependent protein kinase (DNA-PK) but increased phospho-p53 tumor suppressor protein (p-p53), phospho-ataxia telangiectasia mutated kinase (p-ATM), phospho-histone H2A.X (Ser139) and poly(ADPribose) polymerase (PARP) in the B16F10 cells. Furthermore, we used confocal laser system microscopy to examine the protein expression levels and we found that casticin increased the expression of p-p53 and p-H2A.X in the B16F10 cells. Collectively, casticin induced DNA damage and affected DNA repair proteins in the B16F10 cells in vitro.

\section{Introduction}

It is well known that anti-neoplastic drugs interfere with the structure and functions of DNA directly or indirectly. However, they sometimes not only affect target cells but also normal cells. In light of this, comprehension of the anticancer functions still require investigation in order to reduce the side effects before their use in the direct treatment of patients. Thus, there is not only the need to evaluate the impairment caused by anticancer drugs on the whole organism but also to investigate the effects of genotoxic alterations at a cellular level (1). Currently, numerous compounds from natural plants have been shown to induce cell death via the induction of cell apoptosis. However, the interruption of cell DNA damage is also needed because these effects can lead to cell death. Some anticancer drugs such as cisplatin or etoposide have been shown to induce DNA damage and eventually cell death (2). Thus, focusing on the 
ability of these compounds to interfere with DNA and produce DNA damage will be helpful and critical to understand how these compounds induce cell death.

Casticin, one of the ingredients derived from Fructus viticis (3), has been shown to exhibit anticancer activity in prostate (4), breast (5), colon $(6,7)$, lung $(8,9)$, cervical $(10)$, gastric (11) and ovarian cancer (12), glioma (13) and leukemia (14) Recently it was reported that forkhead box O3 (FOXO3a) is a critical mediator of the inhibitory effects of casticin on apoptosis in breast cancer cells (3). Furthermore, casticin significantly induced cell apoptosis through the activation of the apoptosis signal-regulating kinase 1-c-Jun N-terminal kinase (ASK1-JNK)-Bim signaling cascade and the accumulation of reactive oxygen species (ROS) in colon cancer cells (15). However, there is no available information to show that casticin induces cell apoptosis in melanoma cancer cells. Furthermore, there is no report showing that casticin induces DNA damage and affects DNA repair-associated protein expression levels in melanoma cells.

After melanoma becomes metastatic melanoma, it is characterized by a high mortality rate (16) due to a universal resistance to standard chemotherapy (17). Hence, the motality rate from unresectable melanoma continues to rise (18). Presently, the ineffectiveness of the treatments available, encourage additional studies to identify novel therapeutic molecules, delivery systems, and/or combination therapies for the treatment of melanoma (19). Casticin may be a potential antitumor agent with both antitumor and anti-proliferative activities. However, the effects of casticin on DNA damage and repair with associated protein expression are not widely known. Thus, the objective of this study was to investigate DNA damage and repair of melanoma B16F10 cells and our results confirmed that casticin induced DNA damage and affected DNA repair systems in vitro.

\section{Materials and methods}

Chemicals and reagents. Casticin, dimethyl sulfoxide (DMSO), propidium iodide (PI), Trypsin-EDTA, penicillin-streptomycin, anti-MGMT (cat no. M3068), anti-PARP (cat no. P248), anti-p-ATMSer1981 (cat no. SBA4300100) and anti- $\beta$-actin (cat no. A5316) were all purchased from Sigma Chemical Co. (St. Louis, MO, USA). Anti-DNA-PK (cat no. PC127) was purchased from Calbiochem (San Diego, CA, USA). Anti-p-H2A.X (cat no. GTX80694) and anti-BRCA1 (cat no. GTX70111), were purchased from GeneTex Inc. (Irvine, CA, USA). Anti-p-p53 (cat no. sc-7997) was obtained from Santa Cruz Biotechnology (Santa Cruz, CA, USA). Anti-MDC1 (cat no. 05-1572) was purchased from Millipore (Billerica, MA, USA). Dulbecco's modified Eagle's medium (DMEM) and fetal bovine serum (FBS) were purchased from Gibco ${ }^{\circledR} /$ Invitrogen Life Technologies (Carlsbad, CA, USA).

Cell culture. The murine melanoma cell line (B16F10) was purchased from the Food Industry Research and Development Institute (Hsinchu, Taiwan). Cells were grown in $75-\mathrm{cm}^{2}$ flasks with DMEM supplemented with $10 \% \mathrm{FBS}, 100 \mathrm{U} / \mathrm{ml}$ penicillin and $100 \mu \mathrm{g} / \mathrm{ml}$ streptomycin at $37^{\circ} \mathrm{C}$ in $5 \% \mathrm{CO}_{2}$ humidified incubators (20).
Cellular morphology and viability examination. B16F10 cells were plated at a density of $1 \times 10^{5}$ cells/well into 12-well plates in DMEM. After the required confluency was reached, cells were exposed to $0,20,30$ and $40 \mu \mathrm{M}$ of casticin for 24 and $48 \mathrm{~h}$ in a $5 \% \mathrm{CO}_{2}$ incubator at $37^{\circ} \mathrm{C}$. Cells were examined and their images were captured by contrast phase microscopy at x200 magnification. Subsequently, the cells were collected, washed and stained with PI $(5 \mu \mathrm{g} / \mathrm{ml})$ in phosphate-buffered saline (PBS) and were analyzed by flow cytometry (Becton-Dickinson, San Jose, CA, USA) for the total percentage of viable cells as previously described (21).

\section{4',6-Diamidino-2-phenylindole dihydrochloride (DAPI)} staining for DNA condensation examination. B16F10 cells $\left(1.5 \times 10^{5}\right.$ cells/well) were plated onto a 6 -well plate for $24 \mathrm{~h}$ and then were exposed to casticin $(30 \mu \mathrm{M})$ for $0,6,24$ and $48 \mathrm{~h}$. After treatment, $4 \%$ formaldehyde in PBS was used to fix cells for $10 \mathrm{~min}$ and then DAPI staining followed. After staining, the cells were examined and their images were captured using a fluorescence microscope at $\mathrm{x} 200$ magnification as previously described (21).

Western blotting for examination of protein expression. B16F10 cells $\left(1 \times 10^{6}\right.$ cells/dish) were plated onto a $10-\mathrm{cm}$ dish and were incubated with $30 \mu \mathrm{M}$ of casticin for $0,6,24$ and $48 \mathrm{~h}$. Cells were collected, suspended in sodium dodecyl sulfate (SDS) sample buffer, sonicated, boiled for $10 \mathrm{~min}$ as previously described (21) and were centrifuged at 12,000 rpm for $15 \mathrm{~min}$. The supernatant was collected and the concentrations of the total protein were determined by Bio-Rad protein assay kit (Bio-Rad Laboratories, Hercules, CA, USA). The cells were electrophoresed by $10 \%$ sodium dodecyl sulfate-polyacrylamide gel (SDS-PAGE) and were transferred to polyvinylidene fluoride (PVDF) membranes (Millipore, Bedford, MA, USA). Immune complexes were formed by incubation of proteins with primary antibodies (anti-MGMT, anti-BRCA1, anti-PARP, anti-p-p53, anti-MDC1, anti-DNA-PK, anti-p-ATM and anti- $\beta$-actin) at $4{ }^{\circ} \mathrm{C}$ (overnight) followed by incubation with a secondary antibody. Immunoreactive protein bands were visualized with a chemiluminescent detection system and the protein expression levels were measured as described by the manufacturer $(20,21)$.

Confocal laser microscopy for examination of protein translocation. B16F10 cells were plated at a density of $1.5 \times 10^{5}$ cells/well on a 6 -well plate and were treated with $30 \mu \mathrm{M}$ of casticin for $48 \mathrm{~h}$. After treatment, cells were fixed in $4 \%$ formaldehyde in PBS for 15 min and $0.1 \%$ Triton X-100 in PBS was added to permeable cells. Subsequently, cells were washed with PBS and blocked with $1 \%$ BSA in PBS for $60 \mathrm{~min}$ and then they were stained with primary anti-p-p53 and anti-p-H2A.X (green fluorescence) overnight followed by staining with a secondary antibody (FITC-conjugated goat anti-mouse IgG). After being washed, cells were stained using PI (red fluorescence) for nuclei. All samples were mounted and photomicrographed by using a Leica TCS SP2 confocal spectral microscope (Leica Microsystems, Heidelberg, Mannheim, Germany) as previously described (21).

Statistical analysis. The comparisons between the casticin-treated and the untreated groups were performed 

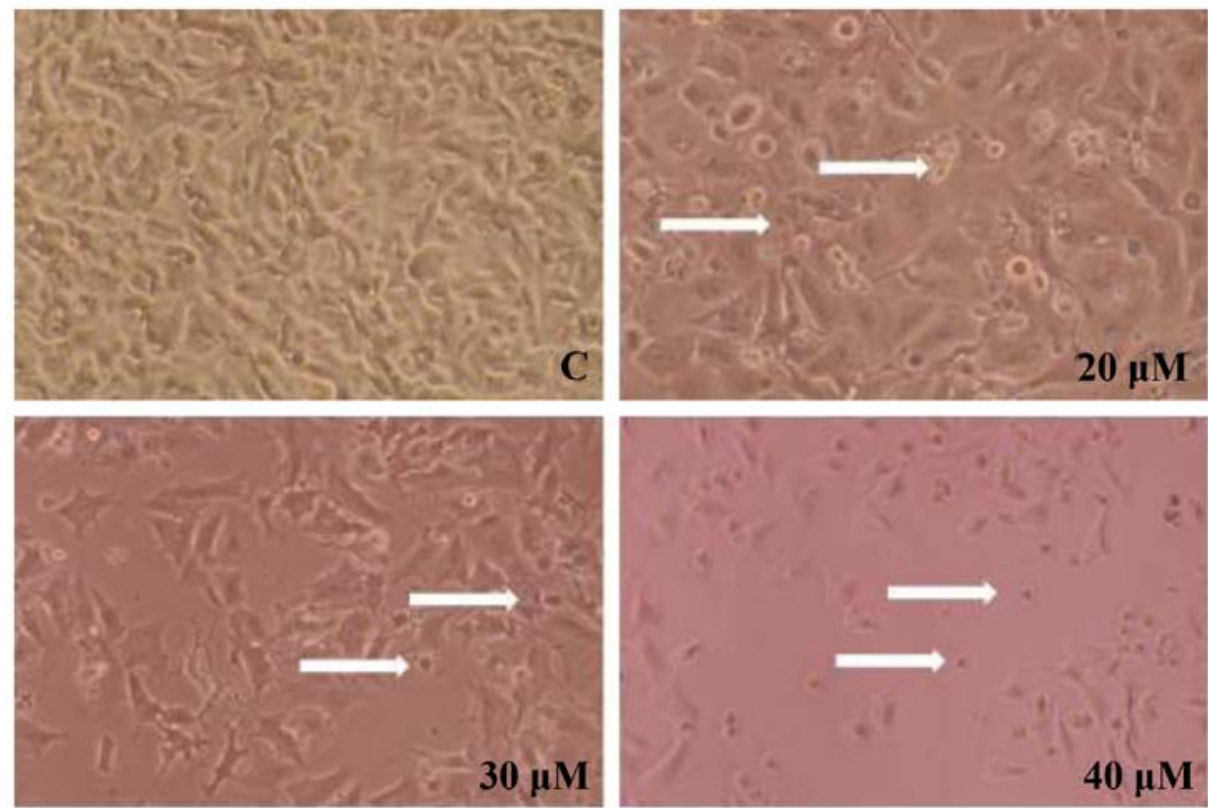

Figure 1. Casticin induces cell morphological changes of viable mouse melanoma B16F10 cells. Cells ( $1 \times 10^{5}$ cells/well) were placed in 12 -well plates and were treated with casticin $(0,20,30$ and $40 \mu \mathrm{M})$ for $48 \mathrm{~h}$. Cells were examined and images were captured using phase contrast microscopy at x 200 magnification.
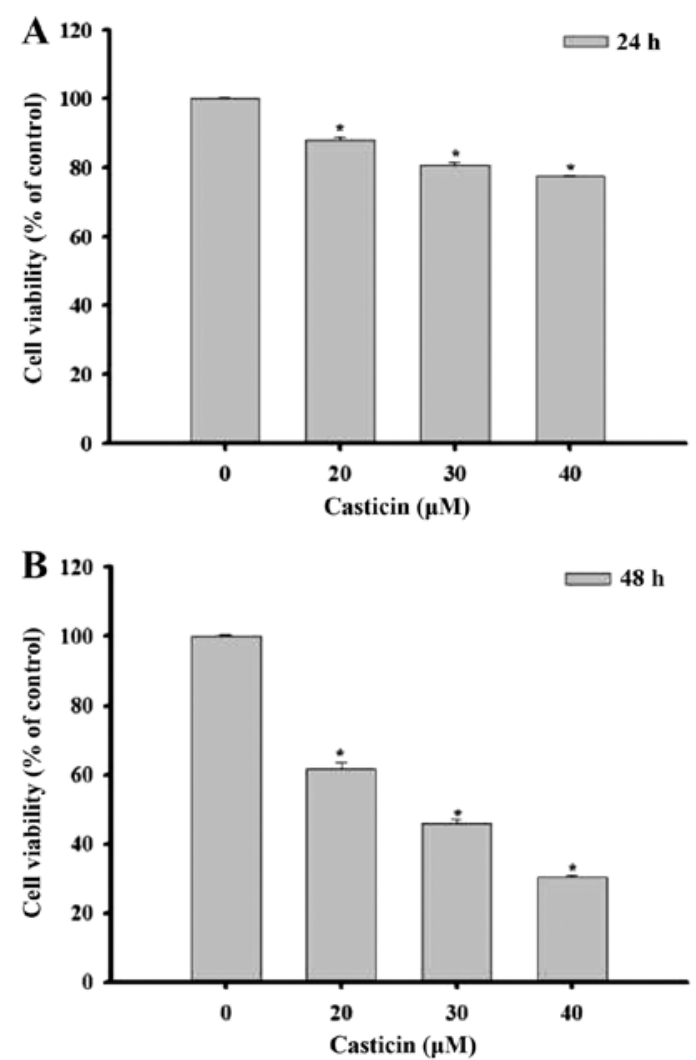

Figure 2. Casticin decreases the percentage of viable mouse melanoma B16F10 cells. Cells $\left(1 \times 10^{5}\right.$ cells/well) were placed in 12-well plates and were treated with casticin $(0,20,30$ and $40 \mu \mathrm{M})$ for 24 (A) and $48 \mathrm{~h}$ (B). Cells were harvested and stained with PI $(5 \mu \mathrm{g} / \mathrm{ml})$ and analyzed by flow cytometry as described in 'Materials and methods'. "P<0.05 indicates a significant difference between the casticin-treated and the untreated groups.

using the Student's t-test, to determine the statistical significance of the differences between these groups. $\mathrm{P}<0.05$ was considered to be significant.

\section{Results}

Casticin induces cell morphology and decreases the total viability of the B16F10 cells. B16F10 cells were treated with various concentrations of casticin $(0,20,30$ and $40 \mu \mathrm{M})$ at 24 and $48 \mathrm{~h}$. Cells were examined for morphological changes and images were captured using a phase contrast microscope at x200 magnification (Fig. 1). The results indicated that casticin induced cell morphological changes in a dose-dependent manner. Cells were collected in order to measure the percentage of viable cells by flow cytometric assay (Fig. 2). The results indicated that the percentage of total cell viability was decreased significantly after treatment with casticin and that this effect was dose-dependent. The treatment of casticin at $48 \mathrm{~h}$ had a higher effect than that at $24 \mathrm{~h}$.

Casticin induces nuclear DNA condensation of B16F10 cells. In order to further confirm whether casticin induced cell death via nuclear DNA condensation in the B16F10 cells, we selected $30 \mu \mathrm{M}$ of casticin for treatment with cells at $0,6,24$ and $48 \mathrm{~h}$, Subsequently the cells were stained with DAPI to examine the formation of DNA condensation (Fig. 3A and B). The results indicated that casticin induced nuclear DNA condensation in the B16F10 cells and this effect was time-dependent.

Casticin affects DNA damage of the associated proteins in the B16F10 cells. Cells were treated with $30 \mu \mathrm{M}$ of casticin for 0,6 , 24 and $48 \mathrm{~h}$ and then DNA damage of the associated proteins such as $O^{6}$-methylguanine-DNA methyltransferase (MGMT), p-H2A.X, breast cancer 1 and early onset (BRCA1), poly(ADP-ribose) polymerase (PARP), phospho-p53 tumor suppressor protein (p-p53), mediator of DNA damage checkpoint 1 (MDC1), DNA-dependent protein kinase (DNA-PK) and phospho-ataxia telangiectasia mutated kinase (p-ATM) were examined by western blot analysis (Fig. 4). The results indicated that casticin decreased the protein levels of MGMT 

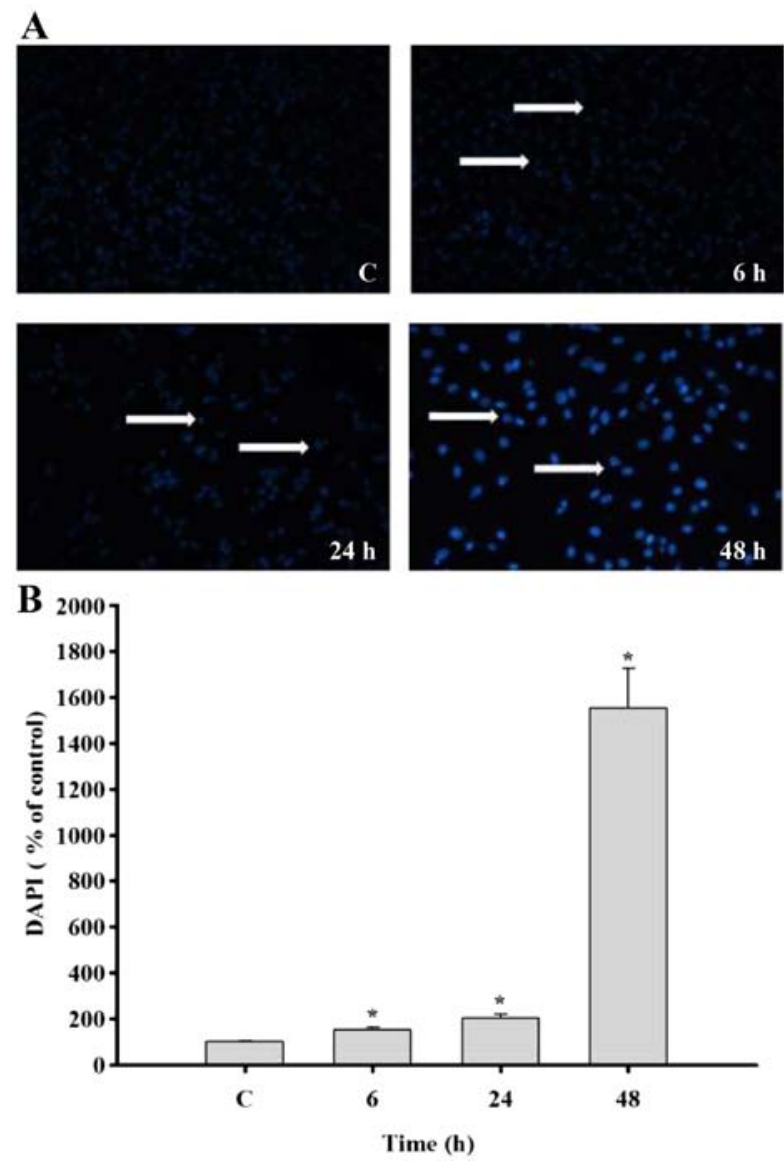

Figure 3. DAPI staining for nuclear DNA damage and condensation in the B16F10 cells. Cells $\left(1.5 \times 10^{5}\right.$ cells/well $)$ were maintained in 6-well plates for $24 \mathrm{~h}$ and were treated with $30 \mu \mathrm{M}$ of casticin for $0,6,24$ and $48 \mathrm{~h}$. Then the cells were stained with DAPI and were examined, and their images were captured using a fluorescence microscope at $\mathrm{x} 200$ magnification as described in 'Materials and methods'. (A) Representative images of DAPI staining; (B) mean of fluorescence (\% of control). "P<0.05 indicates a significant difference between the casticin-treated and the untreated groups.

and BRCA1 (Fig. 4A) and MDC1 (Fig. 4B), but increased the levels of p-H2A.X and PARP (Fig. 4A), p-p53 and p-ATM (Fig. 4B) in the B16F10 cells. These effects are associated with DNA damage and repair that may lead to cell death.

Casticin affects the translocation of p-p53 and p-H2A.X in the B16F10 cells. To further confirm whether casticin affects DNA damage in associated protein translocation in the B16F10 cells, cells were treated with $30 \mu \mathrm{M}$ of casticin and then they were examined by confocal microscopy (Fig. 5). The results revealed that casticin increased the p-p53 (Fig. 5A) and p-H2A.X (Fig. 5B) expression levels in the cytoplasm when compared to the control groups and these observations indicate that casticin induces DNA damage and repair and may also regulate p-p53 and p-H2A.X in the cytoplasm in the B16F10 cells.

\section{Discussion}

Based on the review of the literature, casticin was found to induce cell death (cytotoxic effects) via both induction of cell cycle arrest and apoptosis in many types of human cancer

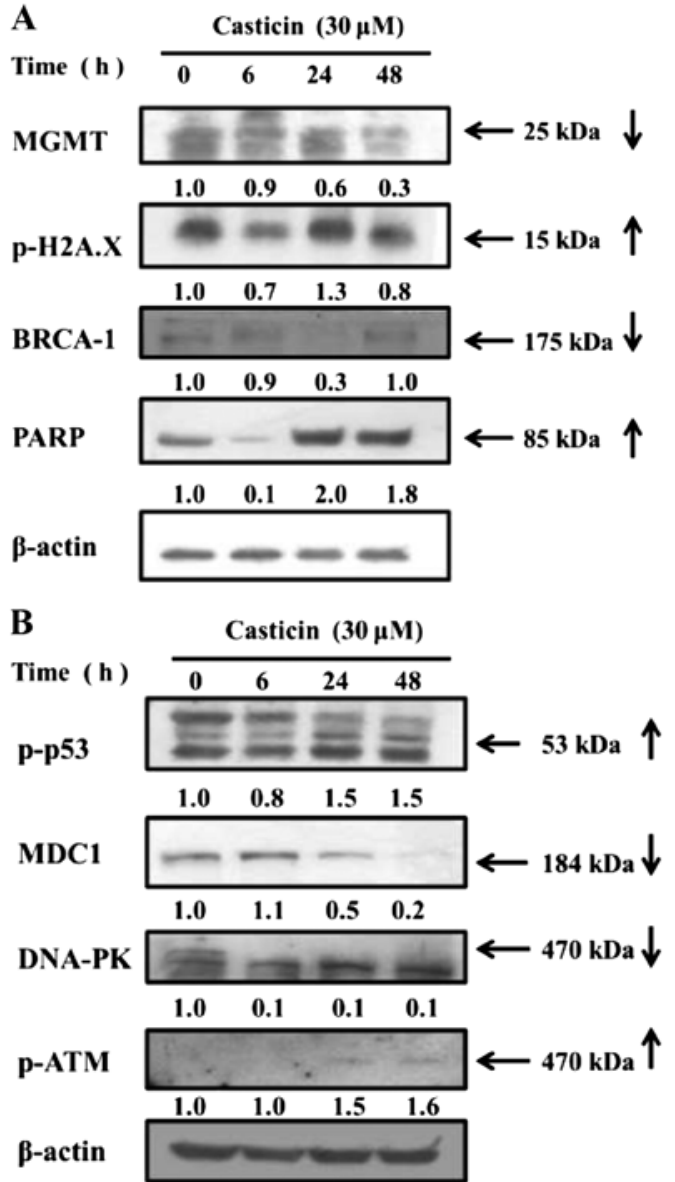

Figure 4. Western blot analysis of protein levels of the proteins associated with DNA damage and repair in the B16F10 cells. Cells $\left(1 \times 10^{6}\right.$ cells/well $)$ were placed in a $10-\mathrm{cm}$ dish and then were incubated with $30 \mu \mathrm{M}$ of casticin for $0,6,24$ and $48 \mathrm{~h}$. The total amount of proteins was determined and the amounts of protein from each treatment were measured by SDS-PAGE and immunoblotting as described in 'Materials and methods'. (A) MGMT, p-H2A.X, BRCA1 and PARP. (B) p-p53, MDC1, DNA-PK and p-ATM.

cells, but there is no available information showing that casticin induces DNA damage and repair and affects associated protein expression in human cancer cells. Therefore, in the present study, we investigated the cytotoxic effects of casticin and whether, through the induction of DNA damage, it affected DNA repair and associated protein expression levels in mouse melanoma B16F10 cells in vitro. After B16F10 cells were exposed to various concentrations of casticin we found that i) casticin induced cell morphological changes (Fig. 1) and decreased the total cell viability (percentage of viable cells) in a concentration- and time-dependent manner (Fig. 2); ii) a time-dependent increase in nuclear DNA condensation was observed in the B16F10 cells after exposure to casticin, which was assayed by DAPI staining (Fig. 3); iii) casticin decreased the proteins levels of MGMT and BRCA1 (Fig. 4A), and MDC1 (Fig. 4B), and increased the levels of p-H2A.X and PARP (Fig. 4A), p-p53 and p-ATM (Fig. 4B) in the B16F10 cells and these effects were time-dependent; iv) casticin induced DNA damage and repair and may also regulate p-p53 (Fig. 5A) and p-H2A.X (Fig. 5B) which are increased in the cytoplasm when compared to the control groups in the B16F10 cells. 
A
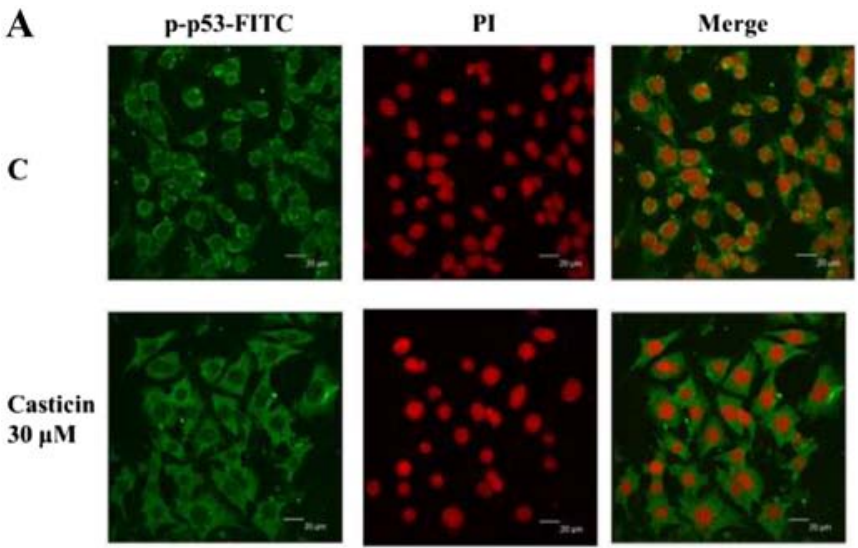

B

p-H2A.X-FITC
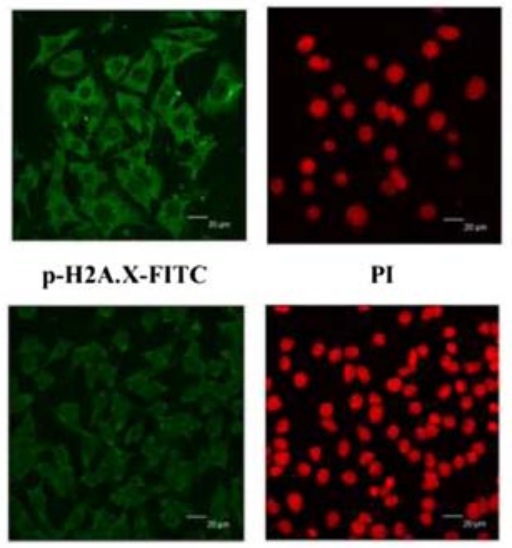

PI
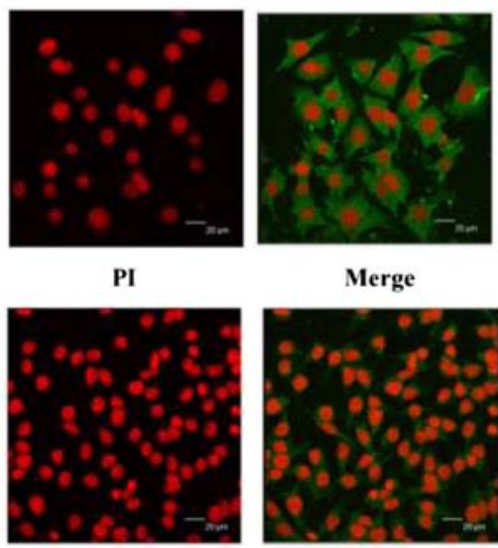

Merge
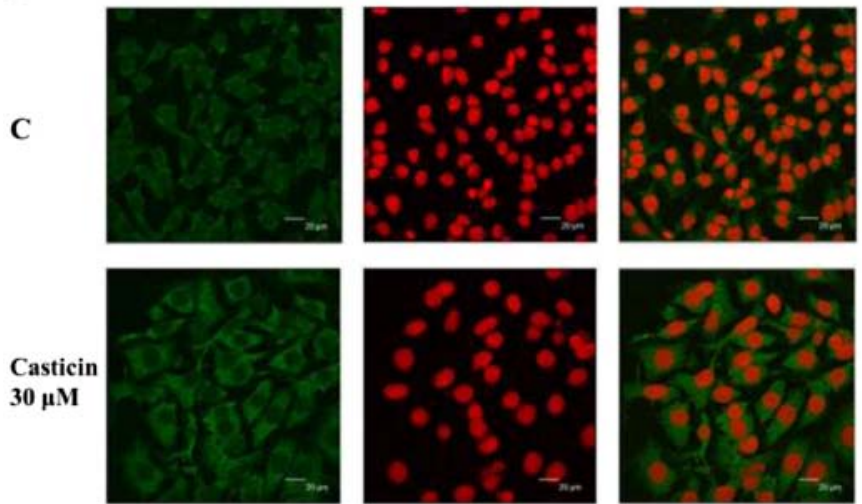

Figure 5. Confocal laser system microscopy was used to examine the protein expression in the B16F10 cells. Cells $\left(1.5 \times 10^{5}\right.$ cells/well $)$ were kept on a 6 -well plate and were incubated with $30 \mu \mathrm{M}$ of casticin for $48 \mathrm{~h}$. Subsequently, they were fixed in $4 \%$ formaldehyde in PBS for 15 min followed by $0.1 \%$ Triton X-100 in PBS for 15 min. Immunostaining was then performed as described in 'Materials and methods'. (A) p-p53; (B) p-H2A.X. Both samples were examined and images were captured using a Leica TCS SP2 confocal spectral microscope.

We observed that casticin induced cell morphological changes and decreased the total percentage of viable B16F010 cells in a dose-dependent manner at 20-40 $\mu \mathrm{M}$. Thus, we further examined whether casticin induced cell death and was associated with induction of DNA damage in the B16F10 cells. Based on the results from Fig. 3, it was revealed that casticin induced DNA damage and condensation in the B16F10 cells which were assayed by DAPI staining, respectively. It has been reported that specific and bulky DNA lesions which trigger cell apoptosis have been identified (22). It has been well documented that DAPI staining can reveal DNA fragmentation and nuclear DNA condensation and our results indicated that casticin induced nuclear DNA condensation in a time-dependent manner. Recently, a new type of anti-neoplastic therapy has emerged, whose aim is to manipulate DNA damage response (DDR) (23-25) as DDR inhibition has been proven as an effective treatment for cancer. It has been reported that oxidative DNA damage has been recognized to be an etiological factor in aging and in the development of systemic diseases including cancer in the human population $(26,27)$. In cells, DNA repair enzymes monitor chromosomes and correct damaged nucleotides to prevent these adverse effects (28).

In the present study, our findings are the first to provide information regarding casticin-induced DNA damage and the

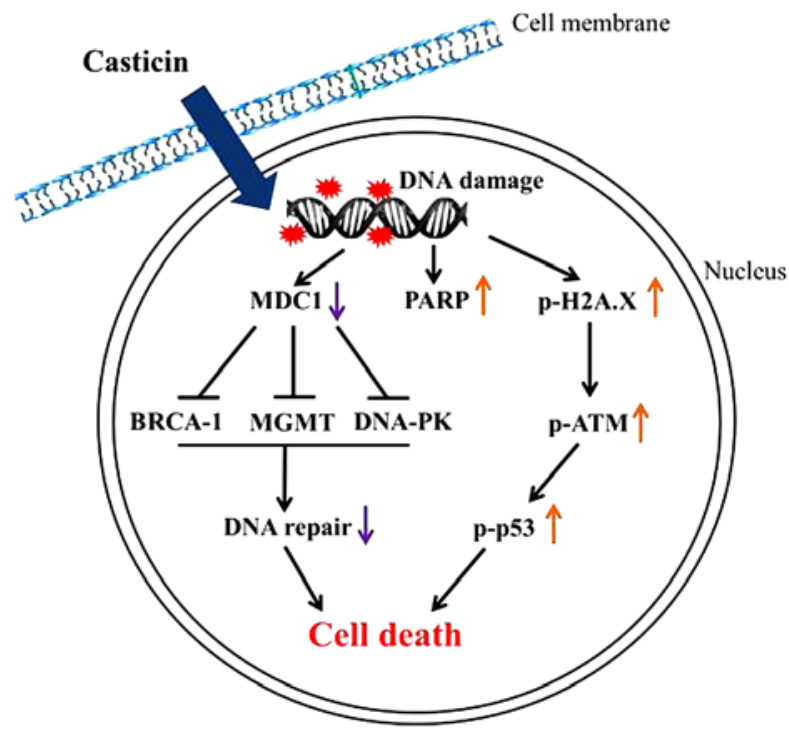

Figure 6. The proposed signaling pathways involved in casticin-induced DNA damage and the effects on DNA repair proteins in the B16F10 cells.

affect on the DNA repair system in the B16F10 cells (Fig. 3). Western blotting (Fig. 4) indicated that casticin induced DNA damage and affected repair in associated protein expression levels such as MGMT and BRCA1 (Fig. 4A), MDC1 and DNA-PK (Fig. 4B) but increased the levels of p-H2A.X and PARP (Fig. 4A) and p-p53 and p-ATM (Fig. 4B) in the $\mathrm{B} 16 \mathrm{~F} 10$ cells. It has been reported that MGMT is a DNA repair enzyme which eliminates $O^{6}$ methylguanines (29) and that the inhibition of MGMT may be strategic in increasing tumor susceptibility to chemotherapy (30). In breast and ovarian cancers, BRCA1 plays an important role in DNA repair in the maintainance of genomic stability (31) and in breast cancer, BRCA1 promoter methylation was found to be positively associated with increased mortality (32). MDC1 and BRCA1 represent important assets in the repair of double-strand breaks after DNA damage occurs $(33,34)$. Furthermore, MDC1 may affect the radiosensitivity of tumor cells (35). It has been reported that DNA-PK is a serine/threonine protein kinase and is expressed in most mammalian cells (36). DNA-PK plays an important role in the main repair pathway of DNA double-strand breaks and cells deficient in DNA-PK exhibit hypersensitivity to radio/chemotherapy (37-39). It has also been reported that anticancer drugs such as 5-FU induce DNA double-strand breaks, and the presence of p-H2A.X which is a phosphorylated form of the histone H2A.X which has been shown to be a specific marker for the detection of these DNA breaks was observed (40). Based on this observation, we suggest that casticin induced double-strand breaks in the B16F10 cells.

Moreover, it has been reported that the ATM/p53 pathway is involved in the apoptosis of various cancer cells induced by chemotherapy drugs (41). Herein, results from the western blot analysis indicated that casticin increased the protein levels of proteins p-p53 and p-ATM (Fig. 4B) in the B16F10 cells which was also confirmed by confocal laser system microscopy examination (Fig. 5). Notably, it has also been reported that antioxidant $N$-acetylcysteine (NAC) pretreatment enhances ATM and p53 phosphorylation, p53 acetylation and H2A.X 
phosphorylation in ovarian cancer cells (42). In view of this, the possible signaling pathways involved in the casticininduced DNA damage and nuclear condensation in the B16F10 cells are summarized in Fig. 6. Thus, further studies should be conducted to elucidate the exact molecular mechanism of casticin-induced DNA damage and how to affect DNA damage and repair-associated signaling pathways.

\section{Acknowledgements}

This study was supported by grant CMU103-ASIA-01 from China Medical University (Taichung, Taiwan) and by grant 103-08 and 103-41 from Cheng Hsin General Hospital (Taipei, Taiwan). Experiments and data analysis were performed in part through the use of the Medical Research Core Facilities Center, Office of Research and Development at China Medical University (Taichung, Taiwan).

\section{References}

1. Parrella A, Lavorgna M, Criscuolo E, Russo C and Isidori M: Eco-genotoxicity of six anticancer drugs using comet assay in daphnids. J Hazard Mater 286: 573-580, 2015.

2. Li X, Tian J, Bo Q, Li K, Wang H, Liu T and Li J: Targeting DNA-PKcs increased anticancer drug sensitivity by suppressing DNA damage repair in osteosarcoma cell line MG63. Tumour Biol 36: 9365-9372, 2015.

3. Liu LP, Cao XC, Liu F, Quan MF, Sheng XF and Ren KQ: Casticin induces breast cancer cell apoptosis by inhibiting the expression of forkhead box protein M1. Oncol Lett 7: 1711-1717, 2014.

4. Weisskopf M, Schaffner W, Jundt G, Sulser T, Wyler S and Tullberg-Reinert H: A Vitex agnus-castus extract inhibits cell growth and induces apoptosis in prostate epithelial cell lines. Planta Med 71: 910-916, 2005.

5. Haïdara K, Zamir L, Shi QW and Batist G: The flavonoid casticin has multiple mechanisms of tumor cytotoxicity action. Cancer Lett 242: 180-190, 2006.

6. Imai M, Kikuchi H, Denda T, Ohyama K, Hirobe $\mathrm{C}$ and Toyoda H: Cytotoxic effects of flavonoids against a human colon cancer derived cell line, COLO 201: A potential natural anti-cancer substance. Cancer Lett 276: 74-80, 2009.

7. Tang SY, Zhong MZ, Yuan GJ, Hou SP, Yin LL, Jiang H and Yu ZY: Casticin, a flavonoid, potentiates TRAIL-induced apoptosis through modulation of anti-apoptotic proteins and death receptor 5 in colon cancer cells. Oncol Rep 29: 474-480, 2013.

8. Koh DJ, Ahn HS, Chung HS, Lee H, Kim Y, Lee JY, Kim DG, Hong M, Shin M and Bae H: Inhibitory effects of casticin on migration of eosinophil and expression of chemokines and adhesion molecules in A549 lung epithelial cells via NF- $\mathrm{B}$ inactivation. J Ethnopharmacol 136: 399-405, 2011.

9. Zhou Y, Peng Y, Mao QQ, Li X, Chen MW, Su J, Tian L, Mao NQ, Long LZ, Quan MF, et al: Casticin induces caspase-mediated apoptosis via activation of mitochondrial pathway and upregulation of DR5 in human lung cancer cells. Asian Pac J Trop Med 6: 372-378, 2013

10. Zeng F, Tian L, Liu F, Cao J, Quan M and Sheng X: Induction of apoptosis by casticin in cervical cancer cells: Reactive oxygen species-dependent sustained activation of Jun N-terminal kinase. Acta Biochim Biophys Sin (Shanghai) 44: 442-449, 2012.

11. Zhou Y, Tian L, Long L, Quan M, Liu F and Cao J: Casticin potentiates TRAIL-induced apoptosis of gastric cancer cells through endoplasmic reticulum stress. PLoS One 8: e58855, 2013.

12. Jiang L, Cao XC, Cao JG, Liu F, Quan MF, Sheng XF and Ren KQ: Casticin induces ovarian cancer cell apoptosis by repressing FoxM1 through the activation of FOXO3a. Oncol Lett 5: 1605-1610, 2013

13. Liu E, Kuang Y, He W, Xing X and Gu J: Casticin induces human glioma cell death through apoptosis and mitotic arrest. Cell Physiol Biochem 31: 805-814, 2013.

14. Shen JK, Du HP, Yang M, Wang YG and Jin J: Casticin induces leukemic cell death through apoptosis and mitotic catastrophe. Ann Hematol 88: 743-752, 2009.
15. Qu L, Liu FX, Cao XC, Xiao Q, Yang X and Ren KQ: Activation of the apoptosis signal-regulating kinase 1 /c-Jun N-terminal kinase pathway is involved in the casticin-induced apoptosis of colon cancer cells. Exp Ther Med 8: 1494-1500, 2014.

16. Garbe $\mathrm{C}$ and Leiter U: Melanoma epidemiology and trends. Clin Dermatol 27: 3-9, 2009.

17. Jilaveanu LB, Aziz SA and Kluger HM: Chemotherapy and biologic therapies for melanoma: Do they work? Clin Dermatol 27: 614-625, 2009.

18. Siegel R, Naishadham D and Jemal A: Cancer statistics, 2012. CA Cancer J Clin 62: 10-29, 2012.

19. Lillehammer T, Engesaeter BO, Prasmickaite L, Maelandsmo GM, Fodstad O and Engebraaten O: Combined treatment with Ad-hTRAIL and DTIC or SAHA is associated with increased mitochondrial-mediated apoptosis in human melanoma cell lines. J Gene Med 9: 440-451, 2007.

20. Chang YM, Velmurugan BK, Kuo WW, Chen YS, Ho TJ, Tsai CT, Ye CX, Tsai CH, Tsai FJ and Huang CY: Inhibitory effect of alpinate Oxyphyllae fructus extracts on Ang II-induced cardiac pathological remodeling-related pathways in $\mathrm{H} 9 \mathrm{c} 2$ cardiomyoblast cells. BioMedicine 3: 148-152, 2013.

21. Chueh FS, Chen YL, Hsu SC, Yang JS, Hsueh SC, Ji BC, Lu HF and Chung JG: Triptolide induced DNA damage in A375.S2 human malignant melanoma cells is mediated via reduction of DNA repair genes. Oncol Rep 29: 613-618, 2013.

22. Roos WP and Kaina B: DNA damage-induced cell death by apoptosis. Trends Mol Med 12: 440-450, 2006.

23. Hsu YC, Weng HC, Lin S and Chien YW: Curcuminoids cellular uptake by human primary colon cancer cells as quantitated by a sensitive HPLC assay and its relation with the inhibition of proliferation and apoptosis. J Agric Food Chem 55: 8213-8222, 2007.

24. Ireson C, Orr S, Jones DJ, Verschoyle R, Lim CK, Luo JL, Howells L, Plummer S, Jukes R, Williams M, et al: Characterization of metabolites of the chemopreventive agent curcumin in human and rat hepatocytes and in the rat in vivo, and evaluation of their ability to inhibit phorbol ester-induced prostaglandin E2 production. Cancer Res 61: 1058-1064, 2001.

25. Ireson CR, Jones DJ, Orr S, Coughtrie MW, Boocock DJ, Williams ML, Farmer PB, Steward WP and Gescher AJ: Metabolism of the cancer chemopreventive agent curcumin in human and rat intestine. Cancer Epidemiol Biomarkers Prev 11: 105-111, 2002.

26. McCall MR and Frei B: Can antioxidant vitamins materially reduce oxidative damage in humans? Free Radic Biol Med 26: 1034-1053, 1999.

27. Ohia SE, Opere CA and Leday AM: Pharmacological consequences of oxidative stress in ocular tissues. Mutat Res 579: 22-36, 2005.

28. Wood RD, Mitchell M, Sgouros J and Lindahl T: Human DNA repair genes. Science 291: 1284-1289, 2001.

29. Christmann M, Verbeek B, Roos WP and Kaina B: $O(6)$-Methylguanine-DNA methyltransferase (MGMT) in normal tissues and tumors: Enzyme activity, promoter methylation and immunohistochemistry. Biochim Biophys Acta 1816: 179-190, 2011.

30. Verbeek B, Southgate TD, Gilham DE and Margison GP: $O^{6}$-Methylguanine-DNA methyltransferase inactivation and chemotherapy. Br Med Bull 85: 17-33, 2008.

31. Venkitaraman AR: Cancer susceptibility and the functions of BRCA1 and BRCA2. Cell 108: 171-182, 2002.

32. Xu X, Gammon MD, Zhang Y, Bestor TH, Zeisel SH, Wetmur JG, Wallenstein S, Bradshaw PT, Garbowski G, Teitelbaum SL, et al: BRCA1 promoter methylation is associated with increased mortality among women with breast cancer. Breast Cancer Res Treat 115: 397-404, 2009.

33. Bartkova J, Horejsí Z, Sehested M, Nesland JM, RajpertDe Meyts E, Skakkebaek NE, Stucki M, Jackson S, Lukas J and Bartek J: DNA damage response mediators MDC1 and 53BP1: Constitutive activation and aberrant loss in breast and lung cancer, but not in testicular germ cell tumours. Oncogene 26: 7414-7422, 2007.

34. Gorgoulis VG, Vassiliou LV, Karakaidos $\mathrm{P}$, Zacharatos $\mathrm{P}$, Kotsinas A, Liloglou T, Venere M, Ditullio RA Jr, Kastrinakis NG, Levy B, et al: Activation of the DNA damage checkpoint and genomic instability in human precancerous lesions. Nature 434: 907-913, 2005.

35. Gou Q, Xie Y, Liu L, Xie K, Wu Y, Wang Q, Wang Z and Li P: Downregulation of $\mathrm{MDC1}$ and 53BP1 by short hairpin RNA enhances radiosensitivity in laryngeal carcinoma cells. Oncol Rep 34: 251-257, 2015. 
36. Jackson SP: DNA-dependent protein kinase. Int J Biochem Cell Biol 29: 935-938, 1997.

37. Belenkov AI, Paiement JP, Panasci LC, Monia BP and Chow TY: An antisense oligonucleotide targeted to human Ku86 messenger RNA sensitizes M059K malignant glioma cells to ionizing radiation, bleomycin, and etoposide but not DNA cross-linking agents. Cancer Res 62: 5888-5896, 2002.

38. Mi J, Dziegielewski J, Bolesta E, Brautigan DL and Larner JM: Activation of DNA-PK by ionizing radiation is mediated by protein phosphatase 6. PLoS One 4: e4395, 2009.

39. Shintani S, Mihara M, Li C, Nakahara Y, Hino S, Nakashiro K and Hamakawa H: Up-regulation of DNA-dependent protein kinase correlates with radiation resistance in oral squamous cell carcinoma. Cancer Sci 94: 894-900, 2003.
40. Matuo R, Sousa FG, Escargueil AE, Grivicich I, Garcia-Santos D, Chies JA, Saffi J, Larsen AK and Henriques JA: 5-Fluorouracil and its active metabolite FdUMP cause DNA damage in human SW620 colon adenocarcinoma cell line. J Appl Toxicol 29: 308-316, 2009

41. Jäämaa S, Af Hällström TM, Sankila A, Rantanen V, Koistinen H, Stenman UH, Zhang Z, Yang Z, De Marzo AM, Taari K, et al: DNA damage recognition via activated ATM and p53 pathway in nonproliferating human prostate tissue. Cancer Res 70: 8630-8641, 2010.

42. Brum G, Carbone T, Still E, Correia V, Szulak K, Calianese D, Best C, Cammarata G, Higgins K, Ji F, et al: N-acetylcysteine potentiates doxorubicin-induced ATM and p53 activation in ovarian cancer cells. Int J Oncol 42: 211-218, 2013. 